\title{
Application of nitrogen fertilizer in maize in Southern Asia: a review
}

\author{
Aplicación de fertilizantes nitrogenados al maíz en Asia meridional: una revisión
}

\author{
Jiban Shrestha ${ }^{1 *}$, Amit Chaudhary ${ }^{2}$ and Dipesh Pokhrel ${ }^{1}$ \\ * Corresponding author. jibshrestha@gmail.com
}

\begin{abstract}
The rate, time and method of nitrogen $(\mathrm{N})$ fertilizer application are strongly related to growth, development, and yield of the crop. This study principally focuses on the role of the nitrogen in growth, development, and production of the maize, emphasizing time and methods of fertilizer application and their suitable rates. The review shows that crop yield increases up to certain limit and declines if applied in an excess amount of nitrogen. Nitrogen affects various physiological and biochemical processes in plant cells that ultimately affect the growth and development of the plant. Nitrogen response by maize differs due to growth stages, environment and genotype of maize. Hybrid and improved maize varieties are more nitrogen-responsive than local varieties of maize. Proper nitrogen applications as basal doses at planting stage, split doses at critical growth stages namely knee high, and flowering stages are necessary for higher grain yield. This review serves as a useful tool to maize researchers and growers for making the right decision on nitrogen application on maize.
\end{abstract}

Keywords: Maize; nitrogen fertilization; crop growth; yield; grain nitrogen content.

\section{Resumen}

La tasa, tiempo y método de aplicación de fertilizantes nitrogenados $(\mathrm{N})$ están fuertemente relacionados con el crecimiento, desarrollo y rendimiento del cultivo. Este estudio se centra principalmente en el papel del nitrógeno en el crecimiento, desarrollo y producción del maíz, enfatizando el tiempo y los métodos de aplicación de fertilizantes y sus tasas adecuadas. La investigación muestra que el rendimiento de los cultivos aumenta hasta cierto límite y disminuye si se aplica una cantidad excesiva de nitrógeno. El nitrógeno afecta varios procesos fisiológicos y bioquímicos en las células de la planta que finalmente afectan el crecimiento y desarrollo de la planta. La respuesta del nitrógeno del maíz difiere debido a las etapas de crecimiento, el medio ambiente y el genotipo del maíz. Las variedades híbridas y mejoradas de maíz son más sensibles al nitrógeno que las variedades locales de maíz. Las aplicaciones apropiadas de nitrógeno como dosis basales en la etapa de siembra, dosis divididas en las etapas críticas de crecimiento, es decir, en las etapas de crecimiento a la altura de la rodilla y de floración, son necesarias para un mayor rendimiento de grano. Esta revisión sirve como una herramienta útil para los investigadores y cultivadores de maíz para tomar la decisión correcta sobre la aplicación de nitrógeno en el maíz.

Palabras clave: Maiz; fertilización de nitrógeno; crecimiento del cultivo; rendimiento; contenido de nitrógeno en grano.

\section{Role of nitrogen in maize}

Maize (Zea mays L.) is the third most important crop worldwide following rice (Oryza sativa L.) and wheat (Triticum aestivum L.). The maize kernel is composed of approximately $72 \%$ starch, $10 \%$ protein, $5 \%$ oil, $2 \%$ sugar, and $1 \%$ ash with the remainder being water (Perry, 1988). The use of nitrogen fertilizers results in higher biomass and protein yield and increases the concentration of protein in the plant tissue. As the protein concentration of corn grain increases, zein makes up an increasing proportion of the protein (Tsai et al., 1992). Nitrogen often affects the amino acid composition of the protein, and thus the quality of nutrients. In cereals, an abundant supply of nitrogen reduces the relative contribution of lysine and threonine, thus reducing the biological value of the protein. Increased nitrogen supply often leads to kernel integrity and strength, resulting in better milling properties of the grain (Blumenthal et al., 2008). Nitrogen regulates the efficiency of the use of nutrients in the plant. The nitrogen affects various physiological and biochemical processes in plant cells and, ultimately, affects growth and development (Brady, 1990). In proteins, alkaloids, nucleic acids, coenzymes, Porphyrins, nitrogen is the main ingredient. The Porphyrins are responsible for the inheritance, metabolic process and growth of plants. Porphyrins are the main component of cytochrome and chlorophyll (Jain, 2000). The protoplast of plant cells contains mainly nitrogen. It plays an essential role in the growth and proper development of the plant. The lack of nitrogen reduces the growth of the plants and lower yields.

\footnotetext{
${ }^{1}$ Nepal Agricultural Research Council, National Commercial Agriculture Research Program, Pakhribas, Dhankuta, Nepal

2 Tribhuvan University, Institute of Agriculture and Animal Sciences, Lamjung Campus, Lamjung, Nepal
} 
On the contrary, when optimum levels of nitrogen are used, higher yields are produced due to the larger leaf area and the proper growth of the plant.

In addition to its function in the creation of green tissue, nitrogen plays a very important role in the development of the ear and kernel. Studies on nitrogen translocation in the plant showed that nitrogen appears to move from other plant tissues to the ear before silking, apparently in the case of the nitrogen-intense process of kernel embryo formation (Ciampitti and Vyn, 2010).

\section{Time and methods of nitrogen application in maize}

The timing of nitrogen application affects the yield (Bhattarai et al., 2004). In two split dose methods, half of the nitrogen used as the basal dose and other parts of the plant during the Knee high stage are inevitable. Of course, there is a need for half of the total nitrogen remaining at knee high and tasseling stage as equal split doses are necessary. Crop productivity and the availability of nitrogen are unfavorable when used very late in the growing season. When a small amount of nitrogen is used in the initial stages of growth, the rate of nitrogen absorption is greatly reduced by the plant. During central of vegetative growth, maize plant starts to uptake Nitrogen at a faster rate and continues at silking stage to be at peak point (Hanway, 1963). Use of nitrogen in early plant growth improves yield and improves vegetative growth and development, and when is given in later stages of plant growth, late maturity and maturation cannot adequately promote the final yield. Although the level of nitrogen in the grain increases, it is used in later growth stages (Sankaran and Subbiah Mudaliar, 1997).

Therefore, an excellent method of fulfilling a higher demand for Nitrogen could be its application during tasseling and silking stages. Maximum grain and better biomass yield observed after the application of Nitrogen (a) $80 \mathrm{~kg} / \mathrm{ha}$ in two split doses; half part applied at sowing as basal and remaining half during knee-high stage as side dress respectively. Nurudeen et al. (2015) found that the application of nitrogen fertilizer @ $80 \mathrm{~kg} \mathrm{~N} / \mathrm{ha}$ gave higher benefit cost ratio (1.5). Bhattarai et al. (2004) found that during the sowing, earthing up and silking stages, the nitrogen applied at 3 equal divided doses to $60 \mathrm{~kg} / \mathrm{ha}$, maximized the yield of corn grain.

In comparison to traditional broadcast fertilization, fertilization in rows or fertilization in rows combined partly with top dressing increased the values of a percentage of fertilizer nitrogen in the total nitrogen uptake as well as the agricultural and physiological effectiveness of the nitrogen use (Szulc et al., 2016).

\section{Effect of nitrogen on growth of maize}

Maize is a plant that requires a high quantity of nutrients due to its enormous nutrient utilizing capacity. A higher volume of nitrogen is required for higher yield. Nitrogen is required in a more significant amount than other nutrients.
Low yields occur when less nitrogen is used during the stages of tasseling and silking stages, but factors such as nutrient in soil, relief, variety and the expected value of maize yield influence the need. The general nutritional recommendation for corn crops is 120: $60: 40 \mathrm{~kg} / \mathrm{ha}, \mathrm{N}$, $\mathrm{P}$, and K respectively (Singh and Singh, 2002). The rate of application of nitrogen affects the yield of corn (Abebe and Feyisa, 2017). The excessive use of nitrogen in the plants causes continued growth and results in late maturation period. Similarly, lodging occurs due to weak stems with reduced cell walls (produced by overuse of nitrogen). Resistance to pests and diseases of the plants also decreased due to high nitrogen consumption. The capacity of the crop to absorb and use nutrients in the soil depends on the presence of nitrogen in the plants. Therefore, maize yield is reduced due to lack and excess of nitrogen, so the use of nitrogen fertilizers plays an important role in better yields (Goydani and Singh, 1968). The efficient use of nitrogen varies from 150 to $200 \mathrm{~kg} / \mathrm{ha}$ (Mkhabela and PaliShikhulu, 2001).

Diallo et al. (1997) found that leaf senescence got increased due to smaller leaf area and less photosynthesis due to nitrogen deficiency. When nitrogen consumption increased from 0 to $150 \mathrm{~kg} / \mathrm{ha}$, the height of the plant extended between 164 and $209 \mathrm{~cm}$ (Sharma, 1973). The leaf area index was also significantly higher in all phases of plant growth when nitrogen was used in the range of 60 to $180 \mathrm{~kg} / \mathrm{ha}$. Thakur et al. (1998) found that increment of amount of Nitrogen applied results more leaf number and thicker stem. Leaf area and leaf number significantly increased by both rate and application of Nitrogen (Hati and Panda, 1970).

Nitrogen applied to range from 0 to $150 \mathrm{~kg} / \mathrm{ha}$ significantly increased dry matter at every crop growth stages (Terman and Allen, 1974). Shrestha (2015) found early tasseling and silking stages in maize occurred as result of higher nitrogen application at $200 \mathrm{~kg} \mathrm{~N} / \mathrm{ha}$. Rai (1961) reported that application of nitrogen as well as increase in its rate induced earliness both in tasseling and silking stages. Yadav (1990) also found earlier silking occurred due to a higher percentage of Nitrogen applied.

\section{Effect of nitrogen on yield and yield components of maize}

Shrestha (2015) found that the application of higher nitrogen dose $(200 \mathrm{~kg} \mathrm{~N} / \mathrm{ha})$ gave the highest number of cobs/plant (1.09), cob length $(15.90 \mathrm{~cm})$, cob diameter (5.10), number of grains/grain row (32.54, the number of grain rows/cob (14.11), number of grains/cob (459.9) and the greatest test weight $(318.2 \mathrm{~g})$ and shelling recovery (72.14\%). Also, thicker cob diameter was observed (Hati and Panda, 1970). Singh (1973) found that a higher level of Nitrogen markedly increased grain number per cob and grain weight per cob. Application of $210 \mathrm{~kg} \mathrm{~N} / \mathrm{ha}$ maximize ear length to $15.64 \mathrm{~cm}$ (Pokhrel et al., 2009). Likewise, Nitrogen applied to range 60 to $240 \mathrm{~kg} / \mathrm{ha}$ effectively improved stover yield (Krishnamoorthy et al., 
1974). Yadav (1990) found that in comparison to 0 and 30 $\mathrm{kg} \mathrm{N} /$ ha applied, grain:stover ratio for 90 and $60 \mathrm{~kg} \mathrm{~N} / \mathrm{ha}$ were significantly improved. Whereas, grain yield for 80 , 120 and $160 \mathrm{~kg} \mathrm{~N} /$ ha noted to be increased by $114.59 \%$, $160.8 \%$, and $58.3 \%$ respectively compared to $0 \mathrm{~kg} \mathrm{~N} / \mathrm{ha}$ used (Verma and Singh 1976).

Deficiency of Nitrogen showed an increased number of barren crop plants (Singh, 1988). Kamprath et al. (1982) noted that barrenness in plant increased when Nitrogen applied to range above 168 to $280 \mathrm{~kg} /$ ha but significantly reduced when used between 56 to $168 \mathrm{~kg} / \mathrm{ha}$. A higher level of Nitrogen applied enhanced test grain weight (Gokmen et al., 2001; Wajid et al., 2007). Gungula et al. (2007) and Dawadi and Sah (2012) found a higher application rate of Nitrogen effectively increased kernel number per ear and kernel rows number per cob. A higher level of Nitrogen (180 kg N/ha) improved seed yield to $2.85 \mathrm{t} /$ ha of inbred (NML-1) maize (Adhikary and Adhikary, 2013).

\section{Grain nitrogen uptake}

The presence of nitrogen $(\mathrm{N})$ in maize and genotype are two main factors affecting grain yield (GY) and grain nitrogen content (GNC). The high GY is also based on longevity of leaves, which depends on the balance between post-silking $\mathrm{N}$ uptake and remobilization of vegetative $\mathrm{N}$. Due to complex interactions between $\mathrm{N}$ uptake, N-remobilization, dry matter production (DM), GY and GNC, selection of high GNC hybrids as a single target often led to low GY (Uribelarrea et al., 2007).

Nitrogen uptake by the maize plant increases its concentration in both the plant or in the grain due to the higher total dry matter content. The nitrogen applied from 0 to $150 \mathrm{~kg} /$ ha showed a proportional enhancement in grain yield and nitrogen concentration in the various parts of the plant (Ram and Thakur, 1966). Also, Nitrogen used up to $160 \mathrm{~kg} / \mathrm{ha}$ was useful for the nitrogen concentration in the grain, higher nitrogen levels increased both nitrogen absorption and nitrogen content in maize (Ahlawat et al., 1981). In the same way Pokhrel et al. (2009) found that more nitrogen applied produces a larger nitrogen intake per grain due to higher dry matter yield. Dry matter yield positively correlated with the absorption of nitrogen by maize plant (Lian, 1991).

\section{Factors affecting nitrogen requirement in maize}

The rate of nitrogen fertilizer needed to be supplied to a maize monocrop is influenced by the soil nitrogen content (Carefoot et al., 1989), N source (Bache and Heathcoat, 1969; Jones, 1976), soil reaction (Riley and Barber, 1971; Jones, 1976), rainfall (Dennett, 1984), maize maturity period (Mackay and Barber, 1986) and yield level desired (Arnon, 1975). Martins et al. (2008) reported that higher soil nitrogen resulted in higher nitrogen absorption of plants, influencing the physiological, biochemical and agronomic traits.

Improved maize cultivars could be more efficient in using nitrogen fertilizer than the local varieties (Sallah and Twumasi-Afriyie, 1999). Hybrid maize is a heavy feeder and more responsive to nutrients (Sarkar et al., 2000). Muza et al. (2004) found that the commercial maize hybrids require high nitrogen levels and fertile soils and hybrids are more responsive to nitrogen fertilizer.

Plant population ranging between 69,000 and 81,000 plants/ha, showed a significantly higher uptake of nitrogen than the 57,000 plant population/ha observed during 12 leaf and tasseling stages (AL-Kaisi and Yin, 2003).

Adhikari et al. (2016) and Sherchan et al. (2004) also reported that response of nitrogen and its application time to maize differs due to genetic characters, growing season (winter, spring, and summer), maturity period (early and full season), and growing domain (mountain/hill and Terai).

Losses of $\mathrm{N}$ takes place due to several reasons like leaching as well as volatilization from most of the soils, only one nitrogen management strategy may not be reliable, because the loss occurs in various ways. If nitrogen supplied is under the demand of the plants, the efficiency of use of nitrogen increases (Keeney, 1982).

\section{Conclusion}

The nitrogen is essential for physiological and biochemical processes that ultimately affects growth and development. The application of nitrogen up to $200 \mathrm{~kg}$ N/ha increased the growth traits, yield and yield attributing traits. The nitrogen uptake in grain increases with application of increased level of nitrogen up to $150 \mathrm{~kg} \mathrm{~N} /$ ha applied in soil. The amount of nitrogen fertilizer varies with soil and environmental condition as well as genetic architecture of plants. This study suggests that recommended nitrogen application as basal dose at planting stage, split doses at critical growth stages namely knee high, and flowering stages should be applied for enhancing maize production.

\section{Literature Cited}

Abebe, Z., \& Feyisa, H. (2017). Effects of nitrogen rates and time of application on yield of maize: rainfall variability influenced time of $\mathrm{N}$ application. International Journal of Agronomy, Volume 2017, Article ID 1545280, https://doi.org/10.1155/2017/1545280

Adhikari, P., Baral, B.R., \& Shrestha, J. (2016). Maize response to time of nitrogen application and planting seasons. Journal of Maize Research and Development, 2(1), 83-93. $\quad$ http://dx.doi.org/10.3126/jmrd. v2i1.16218

Adhikary, B. H., \& Adhikary, R. (2013). Enhancing effect of nitrogen on grain production of hybrid maize in Chitwan valley. Agronomy Journal of Nepal, 3, 33-41. http://dx.doi.org/10.3126/ajn.v3i0.8984

Ahlawat, I. P. S., Singh, A., \& Saraf, C. S. (1981). Effects of winter legumes on the nitrogen economy and productivity of succeeding cereals. Experimental 
Agriculture, 17(1), 57-62. https://doi.org/10.1017/ $\underline{\mathrm{S} 0014479700011236}$

Al-Kaisi, M. M., \& Yin, X. (2003). Effects of nitrogen rate, irrigation rate, and plant population on corn yield and water use efficiency. Agronomy journal, 95(6), 1475 1482. DOI:10.2134/agronj2003.1475

Arnon, I (1975). Mineral nutrition of maize. International Potash Inst.: Bern

Bache, B.W., \& Heathcote, R.G. (1969). Long-term effects of fertilizers and manure on soil and leaves of cotton in Nigeria. Experimental Agriculture, 5, 241-247. https:// doi.org/10.1017/S001447970000449X

Bhattarai, E. M., Shrestha, S. P., \& Panta, B. B. (2004). Soil fertility management in maize and maize based cropping system in the western hills of Nepal. In Proceedings of the $24^{\text {th }}$ National Summer Workshop on Maize Research and Production in Nepal. (pp. 198206). Organized by NARC, NMRP

Blumenthal, J., Baltensperger, D., Cassman, K. G., Mason, S., \& Pavlista, A. (2008). Importance and Effect of Nitrogen on Crop Quality and Health. Agronomy $\&$ Horticulture. Faculty Publications. University of Nebraska. Available in https://digitalcommons.unl. edu/agronomyfacpub/200

Brady, N. C., \& Weil, R. R. (1990). The nature and properties of soils. (10th ed.) New York: Macmillan.

Carefoot, J.M., Entz, T. \& Bole, J.B. (1989). Relative efficiency of fertilizer $\mathrm{N}$ and soil nitrate at various depths for the production of soft white wheat. Canadian Journal of Soil Science, 69(4), 867- 874. https://doi.org/10.4141/cjss89-087

Ciampitti, I.A., \& Vyn, T. J. (2010). A comprehensive study of plant density consequences on nitrogen uptake dynamics of maize plants from vegetative to reproductive stages. Field Crops Research, 121(1), 2-18. https://doi.org/10.1016/j.fcr.2010.10.009

Dawadi, D. R., \& Sah, S. K. (2012). Growth and yield of hybrid maize (Zea mays L.) in relation to planting density and nitrogen levels during winter season in Nepal. Tropical Agricultural Research, 23(3), 218227. http://doi.org/10.4038/tar.v23i3.4659

Dennett, M.D. (1984). The tropical environment. In: Goldsworthy, P.R. \& Fischer, N.M. (Eds.). The Physiology of Tropical Field Crops, (pp. 1-38). New York: John Wiley.

Diallo, A. O., Adam, A., Akanvou, R. K., \& Sallah, P. Y. K. (1997). Response of S4 maize lines evaluated under stress and non-stress environments. Developing drought-and low N-tolerant Maize. In Proceedings of a Symposium; El Batan, 25-29 Mar 1996. CIMMYT, Mexico.

Gokmen, S., Sencar, O., \& Sak, M. A. (2001). Response of popcorn (Zea mays everta) to nitrogen rates and plant densities. Turkish Journal of Agriculture and Forestry, 25(1), 15-23.
Goydani, B. M., \& Singh, C. (1968). Performance of hybrid maize under varying plant population with three levels of nitrogen and their time of application. Indian Journal of Agronomy. 13 (2), 83-87.

Gungula, D. T., Togun, A. O., \& Kling, J. G. (2007). The effects of nitrogen rates on phenology and yield components of early maturing maize cultivars. Global Journal of Pure and Applied Sciences, 13(3), 319-324. http://dx.doi.org/10.4314/gjpas.v13i3.16711

Hanway, J. J. (1963). Growth stages of corn (Zea mays, L.) 1. Agronomy Journal, 55(5), 487-492.

Hati, N., \& Panda, U. N. (1970). Varietal response of maize (Zea mays L.) to levels of fertilization. Indian Journal of Agronomy, 15(4), 393-394.

Jain, V. K. (2000). Fundamental of plant physiology. S. Chand Limited, India.

Jones, M.J. (1976). Effects of three nitrogen fertilizers and lime on $\mathrm{pH}$ and exchangeable cation content at different depth in cropped soils at two sites in the Nigerian Savanna. Tropical. Agriculture (Trinidad), 53(3), 243-254. https://journals.sta.uwi.edu/ta/index. asp?action $=$ viewPastAbstract\&articleId $=3136 \&$ issue $\underline{\mathrm{Id}=293}$

Kamprath, E. J., Moll, R. H., \& Rodriguez, N. (1982). Effects of nitrogen fertilization and recurrent selection on performance of hybrid populations of corn 1. Agronomy Journal, 74(6), 955-958. DOI:10.2134/ agronj 1982.00021962007400060007x

Keeney, D. R. (1982). Nitrogen management for maximum efficiency and minimum pollution. In Stevenson, F.J. (ed.) Nitrogen in agricultural soils. (p. 605-649). Agron. Monogr. 22. ASA, CSSA, and SSSA, Madison, WI.

Krishnamoorthy, K., Bommegowda, A., Jagannath, M. K., Venugopal, N., Ramachandra-Prasad, T. V., Raghunatha, G., \& Rajashekara, B. G. (1974). Relative production of yield in hybrid, composite and local maize as influenced by nitrogen and population levels I. Grain yield and its components. Indian Journal of Agronomy, 19, 263-266.

Lian, S. (1991). Efficiency of Nitrogen Fertilization on Upland Crops Grown in Multiple Cropping Systems in Taiwan. ASPAC Food \& Fertilizer Technology Center.

Mackay, A.D., \& Barber, S.A. (1986). Effect of nitrogen on root growth of two corn genotypes in the field. Agronomy Journal, 78, 699-703. DOI:10.2134/agronj 1986.00021962007800040028x

Martins, A.O., Campostrini, E., Magalhaes, P.C., Guimaraes, L.J.M., Duraes, F.O.M., Marriel, I.E., \& Netto, A.T. (2008). Nitrogen-use efficiency of maize genotypes in contrasting environments. Crop Breeding and Applied Biotechnology, 8: 291-298.

Mkhabela, M. S., \& Pali-Shikhulu, J. (2001). Response of maize (Zea mays L.) cultivars to different levels of nitrogen application in Swaziland. In Seventh Eastern 
and Southern Africa Regional Maize Conference (Vol. 11, pp. 377-381).

Muza, L., Waddington, S.R., \& Banziger, M. (2004). Preliminary results on the response of nitrogen use efficient OPV and hybrid maize to $\mathrm{N}$ fertilizer on smallholder fields in Zimbawe. In: Integrated approaches to higher maize productivity in the new millennium: Proceedings of the seventh eastern and southern Africa regional maize conference, Nairobi, Kenya, CIMMYT African Livelihoods Program, P. 245.

Nurudeen, A. R., F. M. Tetteh, F. M., Fosu , M., , Quansah, G. W., \& Osuman, A. S. (2015). Improving maize yield on ferric lixisol by NPK fertilizer use. Journal of Agricultural Science, 7(12): 233-237.

Perry, W.P. (1988). Corn as a livestock feed. In Sprague, C.E. \& Dudley, J.W. (eds) Corn and corn improvement, (3rd edition) (pp. 941-963), American Society of Agronomy, Madison, WI.

Pokhrel, B. B., Sah, S. K., Amgain, L. P., \& Ojha, B. R. (2009). Response of promising maize cultivars to different nitrogen levels in winter. In Proceeding of the Tenth Asian Regional Maize Workshop (pp. 479-483).

Rai, K. D. (1961). The response of maize following sorghum to fertilizers and foliar spray of zinc sulphate at Tozi, Sudan. Indian Journal of Agronomy, 5(1), 176-187.

Ram, A., \& Thakur, R. N. (1966). Effect of fertilization on growth, yield and quality of maize. Indian Journal of Agronomy. 11(4), 315-323.

Riley, D., \& Barber, S.A. (1971). Effect of ammonium and nitrate fertilization on phosphorus uptake as related to root-induced $\mathrm{pH}$ changes at the root-soil interface. Soil Science Society of America Journal, 35(2), 301-306. DOI:10.2136/sssaj1971.03615995003500020035x

Sallah, P.Y.K., \& Twumasi-Afriyie, S. (1999). Studies on Performance of Some Open-Pollinated Maize Cultivars in the Guinea Savanna. III. Nitrogen Use Efficiencies of Four Cultivars. Ghana Journal of Agricultural Science, 32(1), 19-26 http://dx.doi. org/10.4314/gjas.v32i1.1909

Sankaran, S., \& Subbiah Mudaliar, V. T. (1997). Principles of Agronomy, (seventh edition). The Banglore Printing and Publishing Co. Ltd., Mysore Road, Bangalore. $267 p$.

Sarkar, A.K., Singh, K.P., Singh, B.P., \& Singh, R.P. (2000). Long term effects of fertilizers, manures and amendments on crop production and soil fertility. Technical Bulletin of Soil Science and Agricultural Chemistry (BAU) No.2/2000. pp. 31- 45.

Sharma, J. J. (1973). Studies on the multiple cropping sequences under different fertility level. Thesis, M. Sc. Ag. H. P. U. Agric. (Complex), Palampur, India.

Sherchan D.P., Neupane, D.D., Uprety, R., Adhikary, B.H., \& Maskey, S.L. (2004). Effects of micronutrients on grain production and improving quality of maize in acidic soils of the Chitwan valley. In Proceedings of the $22^{\text {nd }}$ National summer crops research workshop on maize research and production in Nepal, (pp 193197). Nepal Agricultural Research Institute, NARC, Khumaltar, Lalitpur, Nepal.

Singh, K. K. (1988). Response of maize to nitrogen rates and tassel removal. Thesis, M. Sc. G. B. Pant University of Agric and Tec, Pantnagar, India.

Singh, N. P., \& Singh, R. A. (2002). Scientific crop production. Press Graphics, Delhi-28, India.

Singh, R. K. (1973). Response of maize to nitrogen fertilization. Madras Agric. J., 60, 399-400.

Shrestha, J. (2015). Growth and Productivity of Winter Maize (Zea mays L.) Under Different Levels of Nitrogen and Plant Population. [on line] Dissertation.com, Boca Raton, USA. Available in: http://dissertation. com/books/1612334407

Szulc, P., Waligóra, H., Michalski, T., Rybus-Zajac, M., \& Olejarski, P. (2016). Efficiency of nitrogen fertilization based on the fertilizer application method and type of maize cultivar (Zea mays L.). Plant Soil and Environment, 62(3), 135-142. https://doi. org/10.17221/654/2015-PSE

Terman, G. L., \& Allen, S. E. (1974). Losses of nitrogen and mineral nutrients from corn grown in greenhouse pot experiments 1. Soil Science Society of America Journal, 38(2), 322-326.

Thakur, D. R., Prakash, O., Kharwara, P. C., \& Bhalla, S. K. (1998). Effect of nitrogen and plant spacing on yield, nitrogen uptake and economics in baby corn (Zea mays L.). Indian Journal of Agronomy, 43(4), 668-671.

Tsai, C.Y, Dweikat, I., Huber, D. M., \& Warren, H. L. (1992). Interrelationship of nitrogen nutrition with maize (Zea mays L.) grain yield, nitrogen use efficiency and grain quality. Journal of the Science of Food and Agriculture, 58(1): 1-8. https://doi.org/10.1002/ jsfa. 2740580102

Uribelarrea, M., Moose, S.P. \& Below, F.E. (2007). Divergent selection for grain protein affects nitrogen use in maize hybrids. Field Crops Research, 100(1), 82-90. https://doi.org/10.1016/j.fcr.2006.05.008

Verma, B. S., \& Singh, R. R. (1976). Effect of nitrogen, moisture regime and plant density on grain yield and quality of hybrid maize. India, No. 77-212400. CIMMYT.

Wajid, A., Ghaffar, A., Maqsood, M., Hussain, K., \& Nasim, W. (2007). Yield response of maize hybrids to varying nitrogen rates. Pakistan Journal of Agricultural Sciences, 44(2), 217-220.

Yadav, D. N. (1990). Growth and productivity of maize under different crop sequences and nitrogen rates. Doctoral dissertation, Ph. D. Thesis, GB Pant Univ. of Agric. and Tech., Pantanagar, India. 